\title{
ANALISIS FAKTOR YANG MEMPENGARUHI BESARNYA PROFITABILITAS PADA BANK UMUM SYARIAH DI INDONESIA PERIODE JANUARI 2017- DESEMBER 2018
}

\author{
Mukhamad Zakariya \\ Institut Agama Islam Pangeran Diponegoro Nganjuk \\ e-mail: mukhamad_zakariya@gmail.com
}

\begin{abstract}
The emergence of new Islamic banks creates healthy competition among Islamic banks both in terms of improving services, as well as improving the performance of the banks themselves. As one of the institutions that has an important role in the country's economy, banking regulators need to conduct controlled and comprehensive performance monitoring to improve the performance of Islamic banking so that the bank remains healthy and efficient. Profitability is the most important indicator to measure the performance of a bank. Return on assets (ROA) focuses on the company's ability to earn earnings in the company's operations by utilizing its assets. The purpose of this study is to analyze the influence of the non performing financing factor (NPF), the ratio of operating costs to operating income (BOPO), and financing to deposit ratio (FDR) on profitability in Islamic banking in Indonesia as measured by return on assets. The analytical method used in this study is multiple linear regression. The results of this study indicate that the simultaneous non performing financing $(N P F)$, the ratio of operating costs to operating income (BOPO), and financing to deposit ratio (FDR) affect the return on assets on Islamic banking in Indonesia, while partially non performing financing (NPF) has no effect. The ratio of operating costs to operating income (BOPO) has a negative effect, and financing to deposit ratio (FDR) has a positive effect on profitability in Islamic banking in Indonesia as measured by return on assets.
\end{abstract}

Keywords: Profitability, Non performing financing factor, The ratio of operating costs to operating income, Financing to deposit ratio

\section{Pendahuluan}

Bank adalah badan usaha yang menghimpun dana dari masyarakat dalam bentuk simpanan dan menyalurkan ke masyarakat dalam bentuk kredit dan atau bentuk lainnya dalam rangka meningkatkan taraf hidup rakyat banyak. Dua fungsi pokok bank adalah penghimpunan dana masyarakat dan penyaluran dana kepada masyarakat. Oleh karena itu disebut financial intermediary. ${ }^{1}$

Munculnya bank-bank syariah baru menimbulkan persaingan yang sehat antar bank syariah, baik dalam hal meningkatkan pelayanan jasa, maupun meningkatkan kinerja bank itu sendiri. Sebagai salah satu lembaga yang memiliki peranan penting dalam perekonomian negara, maka regulator perbankan perlu melakukan pengawasan kinerja secara terkontrol dan menyeluruh untuk meningkatkan kinerja perbankan syariah agar bank tersebut tetap sehat dan efisien. $^{2}$

\footnotetext{
${ }^{1}$ Ismail, Perbankan Syariah (Jakarta: Kencana Prenada Media Grup, 2011), 29.

2 Adi Setiawan, "Analisis Pengaruh Faktor Ekonomi, Pangsa Pasar, dan Karakteristik Bank terhadap
} 
Persaingan di lembaga keuangan memang sangat ketat, terutama di dunia perbankan. Banyak perbankan baik konvensional maupun syariah mulai mengeluarkan produk-produk inovatif untuk menarik para nasabah. Persaingan antar perbankan ini tentunya menjadi keuntungan sendiri bagi nasabah, karena nasabah mempunyai banyak pilihan dalam menentukan bank mana yang akan dijadikan mitra kerja sama. Kinerja dan performa suatu bank menjadi faktor utama bagi nasabah dalam menentukan pilihannya.

Profitabilitas merupakan indikator yang paling penting untuk mengukur kinerja suatu bank. Return on asets (ROA) memfokuskan kemampuan perusahaan untuk memperoleh earning dalam kegiatan operasi perusahaan dengan memanfaatkan aktiva yang dimilikinya. Sehingga dalam penelitian ini, ROA digunakan sebagai ukuran kinerja perbankan. Tujuan utama operasional bank adalah mencapai tingkat profitabilitas yang maksimal. ROA penting bagi bank karena ROA digunakan untuk mengukur efektivitas perusahaan di dalam menghasilkan keuntungan dengan memanfaatkan aktiva yang dimilikinya. Profitabilitas merupakan kemampuan bank untuk menghasilkan atau memperoleh laba secara efektif dan efisien. Profitabilitas yang digunakan adalah ROA karena dapat memperhitungkan kemampuan manajemen bank dalam mengelola aktiva yang dimilikinya untuk menghasilkan income. Semakin besar ROA suatu bank, semakin besar pula tingkat keuntungan yang dicapai bank tersebut dan semakin baik pula posisi bank tersebut dari segi penggunaan aset. ${ }^{3}$

Selain itu, dalam penentuan tingkat kesehatan suatu bank, Bank Indonesia lebih mementingkan penilaian ROA daripada ROE karena Bank Indonesia lebih mengutamakan nilai profitabilitas suatu bank yang diukur dengan aset yang dananya sebagian besar berasal dari dana simpanan masyarakat sehingga ROA lebih mewakili dalam mengukur tingkat profitabilitas perbankan. ${ }^{4}$

Tinggi rendahnya profit atau laba yang diperoleh perbankan syariah tentunya terdapat beberapa faktor yang mempengaruhinya, salah satunya faktor dari internal perbankan sendiri, seperti non performing financing (NPF), rasio biaya operasional terhadap pendapatan operasional (BOPO), financing to deposit ratio (FDR) dan lain sebagainya.

Fokus penelitian ini dimaksudkan untuk mengetahui bagaimana pengaruh NPF, BOPO, dan FDR terhadap besarnya profitabilitas bank umum syariah di Indonesia.

\section{Profitabilitas dalam Perbankan Syariah}

Bank Syariah adalah bank yang dalam aktivitasnya, baik penghimpunan dana maupun dalam rangka penyaluran dananya memberikan dan mengenakan imbalan mengacu pada hukum Islam, dan dalam kegiatannya tidak membebankan bunga maupun tidak membayar bunga kepada nasabah. Imbalan yang diterima oleh bank syariah, maupun yang dibayar nasabah tergantung dari akad dan perjanjian antara nasabah dan pihak bank.

Rasio profitabilitas adalah suatu ukuran untuk melihat kemampuan atau usaha sebuah bank dalam menghasilkan keuntungan. Tujuan utama suatu badan usaha pengelola keuangan dalam melakukan usahanya adalah dengan memperoleh keuntungan sehingga rasio profitabilitas menjadi penting. Riyadi menyatakan untuk mengetahui dan menilai baik atau

Profitabilitas Bank Syariah” (Tesis--Universitas Diponegoro Semarang, 2009), 29.

${ }^{3}$ Lukman Dendawijaya, Manajemen Perbankan (Jakarta: Ghalia Indonesia, 2009), 118.

${ }^{4}$ Ibid., 119. 
buruknya kinerja sebuah badan usaha dalam menjalankan kegiatan operasionalnya dapat dilihat dari tingkat profitabilitasnya. ${ }^{5}$

Return on assets (ROA) merupakan rasio keuangan perusahaan yang berhubungan dengan profitabilitas mengukur kemampuan perusahaan menghasilkan keuntungan atau laba pada tingkat aset tertentu. Return on asset (ROA) adalah rasio yang menunjukan hasil (return) atas jumlah aktiva yang digunakan dalam perusahaan. Selain itu, ROA memberikan ukuran yang lebih baik atas profitabilitas perusahaan karena menunjukan efektivitas manajemen dalam menggunakan aktiva untuk memperoleh pendapatan. Dengan mengetahui ROA, kita dapat menilai apakah perusahaan telah efisien dalam menggunakan aktivanya dalam kegiatan operasi untuk menghasilkan keuntungan. ${ }^{6}$

Non performing financing (NPF) meliputi kredit di mana peminjam tidak dapat melaksanakan persyaratan perjanjian kredit yang telah ditandatanganinya, yang disebabkan oleh berbagai hal sehingga perlu ditinjau kembali atau perubahan perjanjian. Dengan demikian, ada kemungkinan risiko kredit bisa bertambah tinggi.

Hubungan NPF dengan profitabilitas bank umum syariah adalah semakin tinggi rasio NPL maka akan semakin buruk kualitas kredit bank yang menyebabkan jumlah kredit bermasalah semakin besar dan menyebabkan kondisi suatu bank semakin bermasalah. timbulnya pembiayaan bermasalah mengakibatkan hilangnya kesempatan memperoleh pendapatan dari pembiayaan yang diberikan, sehingga mengurangi perolehan laba dan berpengaruh buruk bagi profitabilitas bank. Sehingga jika kredit bermasalah semakin besar akan mengakibatkan menurunnya ROA.

Rasio biaya operasional adalah perbandingan antara biaya operasional dan pendapatan operasional. Rasio biaya operasioanl digunakan untuk mengukur tingkat efisiensi dan kemampuan bank dalam melalukan kegiatan operasinya. Mengingat kegiatan utama bank pada prinsipnya adalah bertindak sebagai perantara, yaitu menghimpun dana, maka biaya dan pendapatan operasional bank didominasi oleh biaya bunga dan hasil bunga. Semakin kecil rasio ini berarti semakin efisien biaya operasional yang dikeluarkan bank yang bersangkutan

Hubungan biaya operasional terhadap pendapatan operasional (BOPO) dengan profitabilitas bank umum syariah. Semakin kecil rasio BOPO berarti semakin efisien biaya operasional yang dikeluarkan oleh bank yang bersangkutan, dan setiap peningkatan pendapatan operasi akan berakibat pada berkurangnya laba sebelum pajak yang pada akhirnya akan menurunkan laba atau profitabilitas (ROA) bank yang bersangkutan.

Financing to deposit ratio (FDR) adalah rasio antara jumlah pembiayaan yang diberikan bank dengan dana pihak ketiga yang diterima oleh bank. FDR ditentukan oleh perbandingan antara jumlah pembiayaan yang diberikan dengan dana masyarakat yang dihimpun, yaitu mencakup giro, simpanan berjangka (deposito), dan tabungan. FDR tersebut menyatakan seberapa jauh kemampuan bank dalam membayar kembali penarikan dana yang dilakukan deposan dengan mengandalkan kredit yang diberikan sebagai sumber likuiditasnya. Semakin besar kredit maka pendapatan yang diperoleh naik, karena pendapatan naik secara otomatis

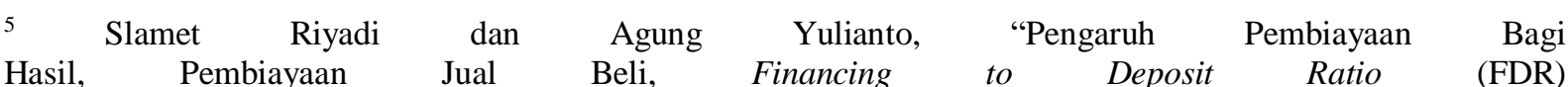
dan Non Performing Financing (NPF) terhadap Profitabilitas Bank Umum Syariah di Indonesia", Jurnal AAJ. Vol. 3. No. 4, (2014), 72.

${ }^{6}$ Kasmir, Bank dan Lembaga Keuangan Lainnya (Jakarta: PT. Raja Grafindo Persada, 2012), 201. 
laba juga akan mengalami kenaikan. FDR merupakan rasio yang mengukur kemampuan bank untuk memenuhi kewajiban keuangan yang harus segera dipenuhi. Kewajiban tersebut berupa call money yang harus dipenuhi pada saat adanya kewajiban kliring, di mana pemenuhannya dilakukan dari aktiva lancar yang dimiliki perusahaan

Hubungan FDR dengan profitabilitas bank umum syariah adalah perbandingan antara jumlah dana yang disalurkan di sisi landing dengan dana yang yang dihimpun di sisi funding. Rasio ini mengukur tingkat penyaluran dana di sisi landing dengan menggunakan dana yang dihimpun di sisi funding. Rasio FDR yang tinggi menunjukkan bahwa suatu bank meminjamkan seluruh dananya (loan-up). Sehingga, dengan penyaluran dana yang tinggi memungkinkan bank umum syariah untuk dapat memperoleh profitabilitas yang lebih tinggi yang berasal dari keuntungan dari penyaluran dana.

\section{Analisis Faktor yang Mempengaruhi Besarnya Profitabilitas pada Bank Umum Syariah di Indonesia Periode Januari 2017-Desember 2018}

Analisis ini menggunakan model analisis regresi linier berganda yang berfungsi untuk mengetahui ada atau tidaknya pengaruh antara variable bebas dengan variable terikat. Untuk pengolahan data yang ada dalam penelitian ini digunakan program SPSS.

Berdasarkan hasil analisis, diperoleh persamaan regresi linier berganda sebagai berikut:

$$
\begin{aligned}
& Y=\beta 0+\beta 1 X_{1}+\beta 2 X_{2}+\beta 3 X_{3}+\mu \mathrm{i} \\
& Y=7,383+0,024 X_{1}-0.107 X_{2}+0.042 X_{3}
\end{aligned}
$$

Di mana:

$\beta 0=$ Konstanta $=7,383$

Artinya, jika diasumsikan $\mathrm{X}_{1}$ (non performing financing), $\mathrm{X}_{2}$ (biaya operasional terhadap pendapatan operasional), $\mathrm{X}_{3}$ (financing to deposit ratio) konstan atau tetap maka nilai $\mathrm{Y}$ (return on asset) akan tetap meningkat sebesar 7,383\%.

$\beta 1=$ Koefisien Regresi untuk $X_{1}=0,024$

Artinya, setiap kenaikan $\mathrm{X}_{1}$ (non performing financing) sebesar $1 \%$ akan menyebabkan kenaikan $\mathrm{Y}$ (return on asset) sebesar $0,024 \%$ dengan asumsi $\mathrm{X}_{2}$ dan $\mathrm{X}_{3}$, Konstan.

$\beta 2=$ Koefisien Regresi untuk $X_{2}=(-0.107)$

Artinya, setiap kenaikan $\mathrm{X}_{2}$ (biaya operasional terhadap pendapatan operasional) sebesar $1 \%$ akan menyebabkan penurunan Y (return on asset) sebesar - $(-0.107 \%$ $\mathrm{X}_{1}$ dan $\left.\mathrm{X}_{3}\right)$.

$\beta 3=$ Koefisien Regresi untuk $X_{3}=0.042$ Artinya, setiap kenaikan $\mathrm{X}_{3}$ (financing to deposit ratio) sebesar $1 \%$ akan menyebabkan kenaikan Y (return on asset) sebesar 0.042 dengan asumsi $\mathrm{X}_{1}$ dan $\mathrm{X}_{2}$, Konstan. 


\section{Koefisien Determinasi (R2)}

Tabel 1.1.

Koefisien Determinasi $\left(\mathrm{R}^{2}\right)$

\begin{tabular}{|l|l|c|}
\hline Variabel Terikat & \multicolumn{1}{|c|}{ Variabel Bebas } & \multicolumn{1}{|c|}{$\begin{array}{c}\text { Koefisien } \\
\text { Determinasi }\left(\mathbf{R}^{2}\right)\end{array}$} \\
\hline \multirow{5}{*}{ Return On Aset } & $\begin{array}{l}\text { Non performing financing } \\
\left(\mathrm{X}_{1}\right)\end{array}$ & \multirow{2}{*}{$\begin{array}{l}\text { Biaya operasional terhadap } \\
\text { pendapatan operasional }\left(\mathrm{X}_{2}\right)\end{array}$} \\
\cline { 2 - 2 } & $\begin{array}{l}\text { Financing to deposit ratio } \\
\left(\mathrm{X}_{3}\right)\end{array}$ & \\
\hline
\end{tabular}

R2 $(\mathrm{R}$ Square $)=$ Koefisien determinasi sebesar 0,898 atau dibulatkan menjadi 0,90. Artinya, $90 \%$ dari seluruh pengamatan menunjukkan bahwa variabel bebas mampu menjelaskan variasi variabel terikatnya, serta sisanya yang $10 \%$ adalah dipengaruhi faktor lain yang tidak tampak pada model galatnya atau biasa disebut (variabel pengganggu). Jadi hubungan antara variabel bebas dengan variabel terikat sangat kuat karena besarnya $\mathrm{R}$ Square mendekati 1, yaitu 0,89 atau dibulatkan jadi 0,90.

\section{Uji Secara Simultan (Uji f)}

Tabel 1.2.

Analisis Varian (ANOVA)

\begin{tabular}{|c|r|c|r|c|c|c|}
\hline Model & Jumlah Kuadrat & Df & Kuadrat Tengah & $F_{\text {Hitung }}$ & $F_{\text {Tabel }}$ & Sig. \\
\hline Regression & 1.347 & 3 & 0.449 & 58.400. & 3.10 &, $000(\mathrm{a})$ \\
\hline Residual & 0.154 & 20 & 0.008 & & & \\
\hline Total & 1.501 & $\mathbf{2 3}$ & & & & \\
\hline
\end{tabular}

Dari hasil pengujian secara simultan menunjukkan bahwa $F_{\text {Hitung }}$ sebesar 58,400 > dan $F_{\text {Tabel }}$ sebesar 3,10. Artinya, H0 ditolak dan H1 diterima. Serta prob.Sig sebesar 0,000 dan $<\alpha$ sebesar 5\%. Dengan demikan secara simultan $\mathrm{X}_{1}$ (non performing financing), $\mathrm{X}_{2}$ (biaya operasional terhadap pendapatan operasional), $\mathrm{X}_{3}$ (financing to deposit ratio) berpengaruh secara nyata dan signifikan terhadap Y (return on asset).

\section{Uji Secara Parsial (Uji t)}

Tabel 1.3.

Hasil Uji Hipotesis secara parsial

\begin{tabular}{|l|c|c|c|c|}
\hline \multicolumn{1}{|c|}{ Model } & $\mathrm{T}_{\text {Hitung }}$ & $\mathrm{T}_{\text {Tabel }}$ & Sig. & $\mathrm{r}^{2}$ parsial \\
\hline Constant & 7.375 & 2,074 &, 000 & \\
\hline $\begin{array}{l}\text { Non performing financing } \\
\left(\mathrm{X}_{1}\right)\end{array}$ & 0.435 & 2,074 &, 668 &, 031 \\
\hline $\begin{array}{l}\text { Biaya operasional terhadap } \\
\text { pendapatan operasional }\end{array}$ & -9.001 & 2,074 &, 000 &,- 644 \\
\hline
\end{tabular}




\begin{tabular}{|l|l|l|l|l|}
\hline$\left(\mathrm{X}_{2}\right)$ & & & & \\
\hline $\begin{array}{l}\text { Financing to deposit ratio } \\
\left(\mathrm{X}_{3}\right)\end{array}$ & 4.136 & 2,074 &, 001 &, 296 \\
\hline Variabel terikat (return on asset) \\
\hline
\end{tabular}

1. Pengaruh secara parsial $\mathrm{X}_{1}$ (non performing financing) terhadap $\mathrm{Y}$ (return on asset).

Dari pengujian secara parsial didapat hasil $t_{\text {hitung }}$ sebesar 0,435 dan $t_{\text {tabel }}$ sebesar 2,074 dengan nilai signifikan sebesar 0.668. Maka H0 diterima dan H1 ditolak sehingga dapat disimpulkan bahwa secara parsial X1 (non performing financing) tidak terbukti berpengaruh secara nyata terhadap Y (return on asset).

2. Pengaruh secara parsial $\mathrm{X}_{2}$ (biaya operasional terhadap pendapatan operasional) terhadap Y (return on asset).

Dari pengujian secara parsial didapat hasil $t_{\text {hitung }}$ sebesar $-9,001>$ dan $t_{\text {tabel }}$ sebesar 2,074 dengan nilai signifikansi sebesar 0,000. Maka H0 ditolak dan H1 diterima sehingga dapat disimpulkan bahwa secara parsial $\mathrm{X}_{2}$ (biaya operasional terhadap pendapatan operasional) berpengaruh secara nyata signifikan dan berhubungan terbalik terhadap $\mathrm{Y}$ (return on asset).

3. Pengaruh secara parsial $\mathrm{X}_{3}$ (financing to deposit ratio) terhadap $\mathrm{Y}$ (return on asset).

Dari pengujian secara parsial didapat hasil thitung sebesar 4,136> dan $t_{\text {tabel }}$ sebesar 2,074 dengan nilai signifikan sebesar 0,001. Maka H0 ditolak dan H1 diterima yang berarti secara parsial $\mathrm{X}_{3}$ (financing to deposit ratio) berpengaruh secara nyata dan signifikan terhadap Y (return on asset).

\section{Uji Asumsi Klasik}

1. Multikolonieritas

Multikolonieritas adalah adanya hubungan yang sempurna atau pasti antara semua atau beberapa variabel bebas dalam model regresi yang dikemukakan. Untuk mengetahui adanya gejala multikolonieritas dapat dilihat pada besarnya VIF. Apabila besarnya nilai VIF kurang dari 10 maka regresi linier tersebut dikatakan bebas dari gejala multikolonieritas dan sebaliknya.

Tabel 1.4.

Tes Multikolonieritas

\begin{tabular}{|c|c|c|c|c|}
\hline $\begin{array}{c}\text { Variabel } \\
\text { Bebas }\end{array}$ & Tolerance & VIF & Ketentuan & Keterangan \\
\hline $\mathrm{X} 1$ & .416 & 2.406 & $<10$ & $\begin{array}{c}\text { Tidak Terjadi } \\
\text { Multikolonieritas }\end{array}$ \\
\hline $\mathrm{X} 2$ & .383 & 2.612 & $<10$ & $\begin{array}{c}\text { Tidak Terjadi } \\
\text { Multikolonieritas }\end{array}$ \\
\hline $\mathrm{X} 3$ & .897 & 1.137 & $<10$ & $\begin{array}{c}\text { Tidak Terjadi } \\
\text { Multikolonieritas }\end{array}$ \\
\hline
\end{tabular}

Dari hasil analisis di atas dapat kita ketahui bahwa dari kelima variabel bebas tersebut besarnya nilai VIF $<10$, yang berarti semua variabel bebas dalam model regresi 
ini tidak terjadi multikolonieritas.

2. Heterokedastisitas

Dalam analisis regresi untuk mendapatkan hasil yang baik salah satu asumsi klasik yang harus dipenuhi adalah homogenitas yaitu dalam regresi linier nilai residual tidak boleh terdapat hubungan dengan variabel bebas, jika asumsi itu tidak dipenuhi maka terjadilah heterokedastisitas. Hal ini bisa didefinisikan dengan menghitung korelasi rank spearman antara residual dengan seluruh variabel bebas.

Tabel 1.5.

Tes Heterokedastisitas

\begin{tabular}{|c|c|c|c|c|}
\hline $\begin{array}{c}\text { Variabel } \\
\text { Bebas }\end{array}$ & $\begin{array}{c}\text { Taraf } \alpha \\
\text { Signifikansi } \\
\text { dari korelasi } \\
\text { Rank } \\
\text { Spearman }\end{array}$ & $>/<$ & $\begin{array}{c}\text { Taraf } \\
\alpha \text { Uji }\end{array}$ & Keterangan \\
\hline X1 & 0.739 & $>$ & 0,05 & $\begin{array}{c}\text { Tidak Terjadi } \\
\text { Heterokedastisitas }\end{array}$ \\
\hline X2 & 0.565 & $>$ & 0,05 & $\begin{array}{c}\text { Tidak Terjadi } \\
\text { Heterokedastisitas } \\
\text { X3 }\end{array}$ \\
\hline
\end{tabular}

Dari hasil pengujian pada penelitian kali ini dapat diketahui bahwa variabel bebas pada penelitian ini tidak terjadi Heterokedastisitas, hasil uji heterokedastisitas ini menunjukkan bahwa hasil taraf signifikansi dari korelasi rank sparman, yaitu (X1 = $0,739, \mathrm{X} 2=0,565, \mathrm{X} 3=0,294)$ lebih besar dari taraf (level of signifikasi) $=\alpha$ uji $(0,05)$, hal ini menunjukkan bahwa tidak terjadinya heterokedastisitas.

3. Autokorelasi

Autokorelasi adalah korelasi anatara dua observasi yang diurutkan berdasarkan kurun waktu (time series) atau data yang diambil pada waktu tertentu (cross sectional). Untuk menguji variabel-variabel yang diteliti apakah terjadi autokorelasi atau tidak dapat digunakan uji Durbin Watson, yaitu dengan cara membandingkan nilai Durbin Watson yang dihitung dengan nilai Durbin Watson (DL dan DU) dalam tabel. Distribusi penentu keputusan dimulai dari 0 (nol) sampai 4 (Empat).

Tabel 1.6.

Model Summary

\begin{tabular}{|c|c|c|c|c|c|}
\hline \multicolumn{5}{|c|}{ Change Statistic } & $\begin{array}{c}\text { Durbin } \\
\text { Watson }\end{array}$ \\
\hline $\begin{array}{c}\text { R Square } \\
\text { Change }\end{array}$ & F Change & df1 & df2 & $\begin{array}{c}\text { Sig F } \\
\text { Change }\end{array}$ & \\
\hline .898 & 58.400 & 3 & 20 & 0.000 & 1.639 \\
\hline
\end{tabular}


Berdasarkan hasil analisis, maka dalam model regresi ini tidak terjadi gejala autokorelasi karena nilai DW tes yang diperoleh adalah sebesar 1,639 yang berada di daerah keragu-raguan atau tanpa kesimpulan. Apabila nilai DW berada di daerah keraguraguan atau di daerah kesimpulan maka masih dikatakan terbebas dari autokorelasi.

Dari hasil pengujian yang telah dilakukan, baik melalui multikolonieritas, heterokedastisitas, maupun autokorelasi dapat ditarik kesimpulan bahwa model analisis regresi linier berganda pada penelitian ini tidak bias.

Dari hasil analisis linier berganda yang dilakukan di atas dapat diketahui bahwa secara simultan atau bersama-sama variabel bebas (non performing financing, biaya operasional terhadap pendapatan operasional, dan financing to deposit ratio berpengaruh positif dan signifikan terhadap besarnya nilai return on asset pada perbankan syariah di Indonesia, jadi apabila secara bersama-sama variabel bebas mengalami kenaikan maka variabel terikatnya juga akan mengalami kenaikan dan sebaliknya.

Namun secara parsial atau individu variabel non performing financing tidak terbukti berpengaruh dan tidak signifikan, biaya operasional terhadap pendapatan operasional berpengaruh negatif dan signifikan, serta financing to deposit ratio berpengaruh positif dan signifikan terhadap variabel terikatnya, yaitu return on asset pada perbankan syariah di Indonesia.

\section{Pengaruh Non Performing Financing terhadap Return on Asset}

Berdasarkan hasil Uji $\mathrm{t}$ yang telah dilakukan non performing financing tidak berpengaruh signifikan terhadap return on asset. Artinya, kenaikan atau penurunan NPF dalam penelitian tersebut tidak berimbas terhadap naik turunnya nilai ROA pada bank umum syariah di Indonesia.

NPF adalah rasio yang digunakan untuk mengetahui pembiayaan yang bermasalah terkait dengan kemungkinan bahwa pada saat jatuh tempo debiturnya atau pengguna dana gagal memenuhi kewajibannya terhadap bank. Pembiayaan merupakan sumber pendapatan terbesar dalam bisnis perbankan dan sekaligus merupakan sumber bencana. Pembiayaan dikatakan sebagai pendapatan jika dalam penyaluran dana atau pembiayaan memperhatikan prinsip kehati-hatian (pembiayaan tepat sasaran baik pengusaha atau objek usaha yang dibiayai) dan dikatakan sebagai sumber bencana jika pembiayaan tidak dengan hati-hati atau bahkan melanggar batas maksimum pemberian kredit (BMPK) akan menyebabkan dalamnya pengaruh pembiayaan bermasalah (NPF) atau bahkan macet terhadap permodalan (CAR).

\section{Pengaruh Biaya Operasional terhadap Pendapatan Operasional terhadap Return on Asset}

Berdasarkan hasil Uji t yang telah dilakukan biaya operasional terhadap pendapatan operasional berpengaruh negatif dan signifikan terhadap return on asset. Artinya, kenaikan BOPO dalam penelitian tersebut akan berimbas terhadap turunnya nilai ROA pada bank umum syariah di Indonesia.

Pencapaian tingkat efisiensi yang tinggi merupakan harapan masing-masing bank, karena dengan tercapainya efisiensi berarti manajemen telah berhasil mendayagunakan 
sumber daya yang dimiliki secara efisien. Tingginya rasio BOPO menunjukkan bahwa bank belum mampu mendayagunakan sumber daya yang dimiliki atau belum mampu menjalankan kegiatan operasionalnya secara efisien, sehingga akan berakibat turunnya profitabilitas. Semakin kecil rasio BOPO menunjukkan semakin efisiennya bank dalam menjalankan kegiatan usahanya, sehingga kesempatan untuk memperoleh keuntungan yang lebih akan semakin tinggi.

\section{Pengaruh Financing to Deposit Ratio terhadap Return on Asset}

Berdasarkan hasil Uji t yang telah dilakukan, financing to deposit ratio berpengaruh positif dan signifikan terhadap return on asset. Artinya, kenaikan BOPO dalam penelitian tersebut akan berimbas terhadap naiknya nilai ROA pada bank umum syariah di Indonesia. Rasio FDR yang tinggi menunjukkan bahwa suatu bank meminjamkan seluruh dananya (loanup). Sehingga, dengan penyaluran dana yang tinggi memungkinkan bank umum syariah untuk dapat memperoleh profitabilitas yang lebih tinggi yang berasal dari keuntungan dari penyaluran dana.

\section{Kesimpulan}

Dari hasil penelitian di atas, maka dapat disimpulkan bahwa pertama, secara simultan atau bersama-sama variabel bebas (non performing financing tidak berpengaruh signifikan terhadap return on asset. Artinya, kenaikan atau penurunan NPF dalam penelitian tersebut tidak berimbas terhadap naik turunnya nilai ROA pada bank umum syariah di Indonesia. Jadi apabila secara bersama-sama variabel bebas mengalami kenaikan maka variabel terikatnya juga akan mengalami kenaikan.

Kedua, secara parsial non performing financing tidak berpengaruh signifikan terhadap return on asset. Artinya, kenaikan atau penurunan NPF dalam penelitian tersebut tidak berimbas terhadap naik turunnya nilai ROA pada bank umum syariah di Indonesia.

Ketiga, secara parsial biaya operasional terhadap pendapatan operasional berpengaruh negatif dan signifikan terhadap besarnya return on asset pada bank umum syariah di Indonesia. Artinya, setiap kenaikan biaya operasional terhadap pendapatan operasional menyebabkan penurunan nilai return on asset.

Keempat, secara parsial financing to deposit ratio berpengaruh positif dan signifikan terhadap besarnya nilai pembiayaan. Artinya setiap kenaikan financing to deposit ratio menyebabkan kenaikan nilai return on asset pada bank umum syariah di Indonesia.

\section{Daftar Rujukan}

Ismail. Perbankan Syariah. Jakarta: Kencana Prenada Media Grup, 2011.

Setiawan, Adi. “Analisis Pengaruh Faktor Ekonomi, Pangsa Pasar, dan karakteristik Bank terhadap Profitabilitas Bank Syariah”. Tesis-- Universitas Diponegoro Semarang, 2009. Dendawijaya, Lukman. Manajemen Perbankan. Jakarta: Ghalia Indonesia, 2009.

Riyadi, Slamet dan Agung Yulianto. "Pengaruh Pembiayaan Bagi Hasil, Pembiayaan Jual Beli, Financing to Deposit Ratio (FDR) dan Non Performing Financing (NPF) terhadap Profitabilitas Bank Umum Syariah di Indonesia". Jurnal AAJ. Vol. 3. No. 4, 2014. 
Kasmir. Bank dan Lembaga Keuangan Lainnya. Jakarta: PT. Raja Grafindo Persada, 2012. Wardiah, Mia Lasmi. Dasar-Dasar Perbankan. Bandung: CV. Pustaka Setia, 2013.

Suliyanto. Ekonometrika Terapan: Teori dan Aplikasi dengan SPSS. Yogyakarta: ANDI, 2011. 